\title{
RESENHAS
}

GALMAN, Sally Campbell (texto e ilustração). 2007. Shane, the lone ethnographer. A beginner's guide to ethnography. Lanham: Altamira Press. 113pp.

\section{Soraya Fleischer}

Doutora em Antropologia Social pela Universidade Federal do Rio Grande do Sul, Centro

Feminista de Estudos e Assessoria

Shane é uma jovem aluna de antropologia, possivelmente no nível de mestrado. No momento, ela está completamente perdida, sem saber por onde começar a organizar seu primeiro projeto de pesquisa. Esta crise iniciática é uma realidade muito familiar para nós, alunos e professores, e consiste justamente no mote que inaugura o livro Shane, the lone ethnographer. A beginner's guide to ethnography. Este curto livro, diagramado em amplas folhas tamanho A4, é mais um manual estadunidense para ensinar antropologia. Contudo, há no mínimo dois aspectos que o diferenciam deste filão. Primeiro, a antropóloga - cartunista e professora da School of Education (University of Massachussets), Sally Campbell Galman escolheu com bastante originalidade a prosa em quadrinhos para contar a história da estudante Shane. Segundo, a autora parte das inseguranças concretas e pessoais vividas pela personagem para apresentar os principais dilemas enfrentados nas etapas de formação. A estética e a linguagem, joviais e informais, e a experiência narrada em primeira pessoa são características que contribuem para criar, com maior facilidade, o vínculo entre leitor/a e personagem. Nós nos reconhecemos e/ou reconhecemos nossos alunos nos passos dados por Shane - e somos impelidos a continuar a leitura.

Como tarefa final de alguma disciplina generalista e/ou introdutória, Shane precisa realizar uma pesquisa e, para tanto, deve decidir qual metodologia irá adotar. Ela é a única aluna da turma a escolher a etnografia e, portanto, lhe restará trabalhar sozinha. Além da solidão, Shane alimenta o mito do heroísmo quase colonialista dos primórdios da antropologia. Como etnógrafa, ela se imagina chegando às porções amplas e ermas do Velho Oeste dos Estados Unidos, pronta para desvendar os segredos ainda velados para os olhos ocidentais. Em seus delírios, está montada a cavalo, porta chapéu, casaco e estrela de xerife. Cactus e um sol inclemente são vistos ao fundo do quadrinho. Este retrato começa a mudar quando Sanjay, colega de turma, telefona para ela oferecendo ajuda para planejar a pesquisa. Ele desconstrói este quadro mítico e ultrapassado e lança-lhe o primeiro desafio: "Shane, mais importante do que escolher o lugar onde a pesquisa vai acontecer, você precisa ter em mente uma pergunta, um problema".

A partir daí, os olhos de Shane se abrem para o mundo, curiosos sobre questões, atores, cenários que mereçam receber uma reflexão mais detida. Voltan- 
do tarde da noite para casa, a mocinha de óculos e cabelos negros e curtos nota que ainda há luzes acesas no prédio de sua escola. Ela se inquieta com o serão extra de seus professores e decide que vai conhecer melhor essa rotina de trabalho.

Com um problema de pesquisa a mão, o próximo passo, explica Sanjay, é escolher qual paradigma científico seguirá ("quantitativo e objetivo", "qualitativo e interpretativista" ou "crítico e teórico" são os três mencionados no livro) e também dominar o que já foi produzido pela literatura. Paradigma e teoria devem ser os pontos de partida. Shane debruça-se a partir daí sobre a extensa bibliografia, varando horas na biblioteca. E começam a aparecer, em sonhos, Ruth Benedict, Franz Boas e Bronislaw Malinowski com ensinamentos que ajudam a responder e a contextualizar as dúvidas que a assombram e quase a paralisam. Eles também sugerem que os conceitos encontrados nos livros pela protagonista componham, de alguma forma, uma genealogia intelectual, um legado cumulativo da disciplina. O amigo Sanjay alerta, porém, ser necessário posicionar-se criticamente diante dos conceitos e saber justificar a escolha de um ou de outro. E embora apareçam e sejam dadivosos em suas maestrias, os gurus e o amigo a deixam repetidamente sozinha. Galman, a autora da HQ, parece insinuar que mesmo sendo fundamental o diálogo, a construção da etnografia é um exercício marcado pelo amadurecimento e pela autoria individuais.

A próxima tarefa é submeter o projeto de pesquisa ao comitê de ética, momento em que Shane descobre as razões históricas que justificaram a criação destas instâncias de controle e avaliação das pesquisas. Com a aprovação de tal chancela, Shane finalmente vai a campo. Em mais um encontro no café francófono de sempre, o amigo Sanjay pergunta-lhe que instrumentos ela vai utilizar em campo.
Observação participante, entrevistas e coleta de material são as técnicas escolhidas pela etnógrafa aprendiz. "E você mesma!", diz Sanjay, provocativo. Shane percebe que ela própria é uma, digamos, "ferramenta em campo" e os dois colegas iniciam uma discussão sobre a inevitabilidade da subjetividade na empreitada etnográfica. Princípios éticos da observação participante, técnicas para conduzir entrevistas estruturadas ou não, imperativo do registro escrito após cada imersão em campo, devolução de resultados aos informantes são questões apresentadas no capítulo seguinte.

Por fim, e sob a inspiradora visita de Clifford Geertz, Shane vai enfrentar o desafio de organizar o material de campo (como descrições no diário, anotações esparsas, entrevistas transcritas, fotos etc.) para, só então, começar a escrever. Diante da página em branco, Geertz sugere que ela seja uma "contadora de histórias", com um plot, personagens, dados analisados, perguntas/temas de pesquisa originais e muita experiência de campo. O finado clássico explica à Shane: "When you write - and do ethnography, you're not 'boiling down' you're telling the whole story: context, life and meaning" (:93).

Embora vários setores - geralmente canônicos - da antropologia brasileira tenham resistido a adotar manuais em suas bibliografias de cursos de pós-graduação, percebo que muitos de nós sentimos a necessidade de avançar a discussão sobre os limites, as platéias e as possibilidades deste tipo de livro. No mínimo, um manual inspira reflexões epistemológicas, já que evidencia as prioridades metodológicas, conceituais e teóricas que uma linhagem prevê para seus sucessores. Alguns assuntos destacados neste livro de Galman servem especialmente como pistas para se conhecer algo da antropologia estadunidense no momento. Por 
exemplo, a naturalização dos comitês de ética e dos consentimentos informados, a proibição radical de que haja sexo em campo (com nativos ou não), o pânico de intoxicação alimentar e doenças tropicais, a enumeração exclusiva de papas da Europa ocidental e dos EUA, a redução das possibilidades teóricas às três principais linhas supracitadas são alguns assuntos. No entanto, é positivo que Shane, no final das contas, tenha escolhido o próprio "quintal" para estudar (i.e, seus professores), indicando como o país tem se aberto para seus temas e problemas (inclusive suas relações de poder), ao invés de manter a tradição de mirar fronteiras internacionais. Ao cabo, Shane percebe que o heroísmo do etnógrafo e o distanciamento físico dificilmente são condicionantes suficientes para produzir uma boa etnografia.

O livro, como reza seu título, é um "beginner's guide to ethnography". Os temas são tratados de forma superficial e rápida, como qualquer "guia" se propõe a fazer. Contudo, o livro pode funcionar como uma proposta inovadora para atrair a atenção dos alunos em sala de aula e, assim, servir de pontapé para leituras complementares e discussões mais complexas. No país, vimos recentemente a boa repercussão de Casa grande \& senzala, de Freyre, como história em quadrinhos. O bom humor, a imagem e a história de uma antropóloga novata (mesmo que ficcional) podem ser profícuos recursos didáticos para driblar os desafios bem conhecidos da experiência docente em antropologia no Brasil, tanto em universidades públicas quanto em particulares, tanto nos cursos de ciências sociais quanto nos inúmeros outros nos quais nos desdobramos para atingir as metas interdisciplinares. 